E3S Web of Conferences 1, 40004 (2013)

DOI: $10.1051 / \mathrm{e} 3$ sconf $/ 20130140004$

(C) Owned by the authors, published by EDP Sciences, 2013

\title{
Chosen metals concentration in hair of sickes people (Arterial hypertension, Hypofunction of kidney, Arteriosclerosis)
}

\author{
J. Trojanowski ${ }^{1}$, P. Trojanowski ${ }^{2}$ and J. Antonowicz ${ }^{1}$ \\ ${ }^{1}$ Department of Environmental Chemistry, Pomeranian University, Arciszewskiego 22, 76-200 Słupsk, \\ trojanowski@apsl.edu.pl \\ ${ }^{2}$ Mental Clinic „Dziekanka”, 62-200 Gniezno, Poland
}

\begin{abstract}
In the present paper studied cumulation $\mathrm{Ca}, \mathrm{Na}, \mathrm{K}, \mathrm{Mg}, \mathrm{Pb}, \mathrm{Cd}, \mathrm{Zn}, \mathrm{Cu}, \mathrm{Al}$ and $\mathrm{Fe}$ in hair of sick persons (arterial hypertension, hypofunction of kidneys, arteriosclerosis) and healthy persons. Contents of selected metals were found to be significant higher in the hair of ill persons compared with those of healthy persons, with the exception of $\mathrm{Ca}, \mathrm{Mg}, \mathrm{Fe}$ and $\mathrm{Zn}$. The concentrations of $\mathrm{Fe}, \mathrm{Zn}, \mathrm{Ca}$ and $\mathrm{Mg}$ in hair were observed to decrease with age of healthy and sick persons and concentrations $\mathrm{Pb}$ and $\mathrm{Cd}$ increased with age those. The ratios of individuals metals concentrations in hair changed depending on age too.
\end{abstract}

Keywords: Heavy metals, hair, arterial hypertension, hypofunction of kidneys, arteriosclerosis

\section{Introduction}

Recently a great deal of interest has been developed in research aimed at exploring occupational, clinical, toxicological and environmental exposure of trace metals along with their impact on human health [7, 9, 13]. Hair analysis can be regarded at as a non-invasive of investigation and a powerful approach to assess healthaffecting variations in the content of both essential and potentially toxic elements in human body. Given its ability to accumulate elements in the keratinous structure, human hair can be considered as a reliable biological indicator of unbalances in the content of minerals in the human body, thus reflecting the health status of an individual as integrated over a period of several months [5, 14]. It is recognized that metal distribution in human hair has marked dependence on age and gender [1,2], and hair related environmental studies can, therefore, be used to differentiate between the health status of various segments of the population [1].

\section{Materials and Methods}

Within years of 2009 - 2010 hair coming 856 persons from the Wielkopolska (Poland) were analyzed (248 persons - ills with arterial hypertension, 214 hypofunction of kidneys, 164 - arteriosclerosis, 230 healthy persons were control group). These persons represented vast spectrum of age (19- 78 years). People were selected by random manner. The hair samples, cut from the nap of the neck close to scalp, as strands $3-5 \mathrm{~cm}$ long, with a pair of plastic scissors, were stored in zipmouthed polythene bags. Prior to analysis, hair samples were cleaned of surface contamination by washing, according to International Atomic Energy Agency (IAEA) instructions [8]. The samples (20-50 mg) were then digested with $5 \mathrm{ml}$ of concentrated nitric acid (Suprapure, 69\%).

An inductively coupled argon plasma atomic emission spectrometr (model Optima 3100 XL, Perkin Elmer) was used for the determination of selected metals ( $\mathrm{Ca}, \mathrm{Na}, \mathrm{K}, \mathrm{Mg}, \mathrm{Pb}, \mathrm{Cd}, \mathrm{Zn}, \mathrm{Cu}, \mathrm{Al}, \mathrm{Fe}$ ) inthe digested samples solutions by following the standard procedure prescribed in the working instructions for the instrument. Samples were analysed in triplicate, the mean metal concentration being within $\pm 1 \%$.

The data were statistically analyzed as repeated measures ANOVA by using the procedure for STATISTICA 8. One-way analysis of variance was used to test for significant differences in study parameters.

\section{Results and Discussion}

Average contents of studied metals in hair of research population are given in Table 1 . Values for healthy persons were in the range reported by Bocca et al., [3], Khalliqu et al.[10], Chojnacka et al. [4], and Pasha et al., 


\section{E3S Web of Conferences}

Tab.1 Average concentrations ( $\mu \mathrm{g} \mathrm{g}^{-1}$ dry weight) of selected metals in scalp hair of ill and healthy persons

\begin{tabular}{lllll}
\hline Metal & $\begin{array}{l}\mathrm{X}^{* \pm \mathrm{SD}} \\
\text { Healthy }\end{array}$ & $\begin{array}{l}\text { Hypofunction } \\
\text { kidneys }\end{array}$ & of Arterial hypertension Arteriosclerosis \\
\hline $\mathrm{Ca}$ & $526.9 \pm 138.1$ & $530.2 \pm 234.1$ & $541.0 \pm 201.2$ & $416.6 \pm 149.8$ \\
$\mathrm{Na}$ & $256 \pm 38.1$ & $472.9 \pm 142.6$ & $473.1 \pm 83.8$ & $378.4 \pm 118.7$ \\
$\mathrm{~K}$ & $159.0 \pm 39.7$ & $259.5 \pm 75.2$ & $262.3 \pm 52.1$ & $277.4 \pm 88.8$ \\
$\mathrm{Mg}$ & $39.65 \pm 8.43$ & $24.74 \pm 15.54$ & $25.70 \pm 7.62$ & $18.06 \pm 8.23$ \\
$\mathrm{Fe}$ & $24.92 \pm 11.71$ & $21.62 \pm 4.95$ & $18.41 \pm 13.18$ & $16.88 \pm .27$ \\
$\mathrm{Cu}$ & $9.05 \pm 2.12$ & $12.58 \pm 3.74$ & $11.46 \pm 2.22$ & $7.78 \pm 2.93$ \\
$\mathrm{Zn}$ & $179.5 \pm 51.9$ & $138.9 \pm 50.5$ & $126.8 \pm 44.2$ & $105.3 \pm 47.4$ \\
$\mathrm{Al}$ & $3.234 \pm 0.719$ & $5.280 \pm 1.458$ & $5.751 \pm 1.265$ & $5.231 \pm 2.047$ \\
$\mathrm{~Pb}$ & $1.690 \pm 0.727$ & $2.957 \pm 1.173$ & $2.613 \pm 1.327$ & $3.162 \pm 1.336$ \\
$\mathrm{Cd}$ & $0.153 \pm 0.095$ & $0.266 \pm 0.112$ & $0.287 \pm 0.160$ & $0.292 \pm 0.150$ \\
\hline
\end{tabular}

[12]. The order of decrease in average concentration for the metals in scalp hair of healthy persons followed the pattern: $\mathrm{Ca}>\mathrm{Na}>\mathrm{Zn}>\mathrm{K}>\mathrm{Mg}>\mathrm{Fe}>\mathrm{Cu}>\mathrm{Al}>\mathrm{Pb}>$ $\mathrm{Cd}$, and for sick persons: $\mathrm{Ca}>\mathrm{Na}>\mathrm{K}>\mathrm{Zn}>\mathrm{Mg}>\mathrm{Fe}>$ $\mathrm{Cu}>\mathrm{Al}>\mathrm{Pb}>\mathrm{Cd}$. The average contents of selected metals were found to be significant higher in the hair of ill persons compared with those of healthy persons, with the exception of $\mathrm{Ca}, \mathrm{Mg}, \mathrm{Fe}$ and $\mathrm{Zn}$. The levels of $\mathrm{Mg}$, $\mathrm{Fe}$ and $\mathrm{Zn}$ were smaller in the hair of ill persons and the level of Ca was significant smaller in the hair of ill with arteriosclerosis. As it results from collected data, there is a relationship between arterial hypertension, hypofunction of kidneys and arteriosclerosis of examined individuals and the level of $\mathrm{Na}, \mathrm{K}, \mathrm{Mg}, \mathrm{Pb}$, $\mathrm{Cd}, \mathrm{Zn}, \mathrm{Cu}, \mathrm{Al}$ in their hair. There is also a relationship between arteriosclerosis and the concentrations $\mathrm{Ca}$ and $\mathrm{Fe}$, and between arterial hypertension and concentration Fe.

Concentrations of some metals in hair changed depending on age in individual groups. The concentrations of $\mathrm{Fe}, \mathrm{Zn}, \mathrm{Ca}$ and $\mathrm{Mg}$ in hair were observed to decrease with age of healthy and sick persons and concentrations $\mathrm{Pb}$ and $\mathrm{Cd}$ increased with age those. In turn, the contents of $\mathrm{Na}$ in hair all study persons no change with age. Potassium content in hair of healthy persons and patients suffering from arteriosclerosis was increasing with age and patients suffering from arterial hypertension but only after 60 years. A trend was observed for copper content in hair of healthy persons and ill with arterial hypertension or hypofunction of kidneys to increase with age, and ill with arteriosclerosis to decrease with age. In turn, the level of $\mathrm{Al}$ in hair of healthy persons were observed to decrease with age and in hair of ills to increase. Based on elemental analysis conclusions may be drawn on the possible relationship between a specific disease and detected deficiency or surplus of bioelements. Inferences may also be presented on an increased risk of incidence of specific diseases, suggesting a potentially harmful effect of toxic elements on the metabolism of the patient $[6,15]$.

Presence some metals in organism influence to concentration other metals. Therefore proportion of concentrations between individuals metals were important too [11]. Table 2 present average values of ratios of individuals metals concentrations in hair of examin persons. On the basis of the results of this research it may be stated that ratios of $\mathrm{Ca} / \mathrm{K}, \mathrm{Ca} / \mathrm{Mg}$, $\mathrm{Ca} / \mathrm{Pb}, \mathrm{Ca} / \mathrm{Cd}, \mathrm{Ca} / \mathrm{Al}, \mathrm{Zn} / \mathrm{Pb}, \mathrm{Zn} / \mathrm{Cd}, \mathrm{Fe} / \mathrm{Pb}$ and $\mathrm{Mg} / \mathrm{Pb}$ show a significant dependence with arteriosclerosis, ratios of $\mathrm{Ca} / \mathrm{Na}, \mathrm{Ca} / \mathrm{Zn}, \mathrm{Ca} / \mathrm{Al}, \mathrm{Zn} / \mathrm{Pb}, \mathrm{Zn} / \mathrm{Cu}$ and $\mathrm{Fe} / \mathrm{Cu}$ with arterial hypertension, and ratios of $\mathrm{Ca} / \mathrm{Mg}, \mathrm{Ca} / \mathrm{Cd}$, $\mathrm{Zn} / \mathrm{Pb}, \mathrm{Zn} / \mathrm{Cd}, \mathrm{Zn} / \mathrm{Fe}, \mathrm{Na} / \mathrm{K}, \mathrm{Na} / \mathrm{Mg}$ and $\mathrm{Fe} / \mathrm{Pb}$ with hypofunction of kidneys. The ratios of individuals metals concentrations in hair changed depending on age.

\section{Conclusions}

The present study evidences that the body metabolism in the arteriosclerosis, arterial hypertension and hypofunction of kidneys patients is being affected by most of the selected metal levels. Imbalances in metals content as a function of these diseases can be observed. The hair levels of $\mathrm{Na}, \mathrm{K}, \mathrm{Al}, \mathrm{Pb}$ and $\mathrm{Cd}$ are significantly higher in the hair of ill persons as compared with healthy persons, and levels of $\mathrm{Mg}$ and $\mathrm{Zn}$ are significantly smaller. The concentrations of $\mathrm{Ca}$ and $\mathrm{Fe}$ are also significantly smaller in the hair of arteriosclerosis patients and $\mathrm{Fe}$ content in arterial hypertension patients too. In turn, content of $\mathrm{Cu}$ are significantly higher in the hair of arterial hypertension and hypofunction of kidneys patients. 


\section{ICHMET 2012}

Tab.2 Average values of ratios of individuals metals concentrations in scalp hair of ill and healthy persons

\begin{tabular}{|c|c|c|c|c|}
\hline Ratio & $\begin{array}{l}\mathrm{X}^{*} \pm \mathrm{SD} \\
\text { Healthy }\end{array}$ & $\begin{array}{l}\text { Hypofunction } \\
\text { kidneys }\end{array}$ & $\begin{array}{l}\text { of Arterial } \\
\text { hypertension }\end{array}$ & Arteriosclerosis \\
\hline $\mathrm{Ca} / \mathrm{K}$ & $3.51 \pm 1.24$ & $2.03 \pm 0.59$ & $2.17 \pm 0.93$ & $1.71 \pm 0.96$ \\
\hline $\mathrm{Ca} / \mathrm{Na}$ & $2.05 \pm 0.45$ & $1.26 \pm 0.76$ & $1.17 \pm 0.46$ & $1.25 \pm 0.73$ \\
\hline $\mathrm{Ca} / \mathrm{Mg}$ & $13.25 \pm 2.18$ & $25.22 \pm 7.28$ & $21.06 \pm 13.99$ & $24.83 \pm 6.23$ \\
\hline $\mathrm{Ca} / \mathrm{Pb}$ & $377.9 \pm 196.5$ & $235.5 \pm 179.3$ & $296.8 \pm 246.9$ & $173.8 \pm 123.2$ \\
\hline $\mathrm{Ca} / \mathrm{Cd}$ & $5112 \pm 3942$ & $2707 \pm 2159$ & $3142 \pm 3314$ & $1846 \pm 1118$ \\
\hline $\mathrm{Ca} / \mathrm{Zn}$ & $3.00 \pm 0.46$ & $3.76 \pm 0.68$ & $4.29 \pm 0.87$ & $4.17 \pm 1.08$ \\
\hline $\mathrm{Ca} / \mathrm{Al}$ & $163.8 \pm 33.1$ & $115.3 \pm 80.5$ & $105.5 \pm 65.1$ & $96.5 \pm 59.9$ \\
\hline $\mathrm{Ca} / \mathrm{Fe}$ & $23.49 \pm 6.93$ & $23.97 \pm 7.41$ & $35.3 \pm 13.1$ & $28.66 \pm 11.30$ \\
\hline $\mathrm{Zn} / \mathrm{Pb}$ & $129.4 \pm 70.4$ & $235.8 \pm 106.3$ & $69.5 \pm 58.1$ & $44.2 \pm 35.8$ \\
\hline $\mathrm{Zn} / \mathrm{Cd}$ & $1758 \pm 1323$ & $691 \pm 512$ & $742 \pm 800$ & $466 \pm 319$ \\
\hline $\mathrm{Zn} / \mathrm{Fe}$ & $7.85 \pm 1.93$ & $6.39 \pm 1.54$ & 8.112 .22 & $7.08 \pm 2.77$ \\
\hline $\mathrm{Zn} / \mathrm{Cu}$ & $22.35 \pm 11.66$ & $13.12 \pm 8.67$ & $12.45 \pm 7.81$ & $14.14 \pm 5.09$ \\
\hline $\mathrm{Na} / \mathrm{K}$ & $1.69 \pm 0.41$ & $1.98 \pm 0.85$ & $1.86 \pm 0.45$ & $1.45 \pm 0.54$ \\
\hline $\mathrm{Na} / \mathrm{Mg}$ & $6.69 \pm 1.44$ & $29.32 \pm 21.14$ & $20.82 \pm 10.70$ & $26.51 \pm 16.26$ \\
\hline $\mathrm{Fe} / \mathrm{Pb}$ & $18.30 \pm 12.56$ & $9.36 \pm 6.23$ & $10.85 \pm 13.26$ & $6.74 \pm 4.85$ \\
\hline $\mathrm{Fe} / \mathrm{Cu}$ & $3.18 \pm 2.31$ & $1.97 \pm 0.99$ & $1.89 \pm 1.91$ & $2.24 \pm 0,98$ \\
\hline $\mathrm{Mg} / \mathrm{Pb}$ & $27.95 \pm 13.49$ & $11.36 \pm 10.25$ & $13.75 \pm 9.91$ & $7.73 \pm 6.21$ \\
\hline
\end{tabular}

\section{References}

[1] Ashraf W., Jaffar M., Anwar K., Ehsan U. 1994. Age and sex based comparative distribution of selected metals in the scalp hair of an urban population from two cities in Pakistan. Environ. Poll., 87, 61-64.

[2] Barbosa A.C., Jardim W., Dorea J.G., Fosberg B., Souza J. 2001. Hair mercury peciation as a function of gender, age, and body mass index in inhabitants of the Negro River basin, Amazon, Brazil. Arch. Environ. Contam. Toxicol., 40, 3, 439-444.

[3] Bocca B., Alimonti A., Senofonte O., Pino A., Violante N., Petrucci F., Sacesario G., Forte G. 2006. Metal changes in CSF and peripheral compartments of parkinsonian patients. J. Neurol. Scien., 248, 2330.

[4] Chojnacka K., Górecka H., Górecki H. 2006. The influence of living habits and family relationships on element concentrations in human hair. Scien. Total Environ., 366, 612-620.

[5] Evans G.J., Jervis R.E.J., 1987. Trace elements in human hair: An international comparison. Radioanal. Nucl. Chem. Art., 110, 613-625.

[6] Goch A., Goch J.H., 2004. Rola kadmu w patogenezie nadciśnienia tętniczego. [Cadmium in arteliar hypertension pathogenesis]. Arterial Hypertension, 8, 1, 41-44.

[7] Hoffman K., Becker K., Friedrich C., Helm D., Krause C., Seifert B. 2000. The German Environmental Survey 1990/1992 (GerES II): cadmium in blood, urine and hair of adults and children. J. Expo. Anal. Environ. Epidemiol., 10, 2, 126-135.
[8] IAEA. Proc. Int. Symp. On Nuclear Activation Techniques in the Life Sciences, Vienna, 1979.

[9] Iyengar G.V., Rapp A. 2001. Human placenta as a 'dual' biomarker for monitoring fetal and maternal environment with special reference to potentially toxic trace elements Part 1: Physiology, function and sampling of placenta for elemental characterization. Sci. Total. Environ., 280, 1-3, 195-206.

[10] Khalique A., Ahmad S., Anjum T., Jaffar M., Shah M.H., Shaheen N., Tariq S. R., Manzoor S. 2005. A comparative study based on gender and age dependence of selected metals in scalp hair. Environ. Monit. Asses., 104, 45-57.

[11] Nowak B., Chmielnicka J. 2000. Relationship of lead and cadmium to essential elements in hair, teeth, and nails of environmentally exposed people. Ecotox. Environ. Safety, 46, 265-274.

[12] Pasha Q., Malik S.A., Iqbal J., Shah M.H. 2007. Characterization and distribution of the selected metals in the scalp hair of cancer patients in comparison with normal donors. Biol. Trace Elem. Res., 118, 207-216.

[13] Vishwanathan H., Hema A., Deepa E., Usha Rani M.V. 2002. Trace metal concentration in scalp hair of occupationally exposed autodrivers. Environ. Monit. Asses. 77, 149-154.

[14] Wilson L.D. (Ed.). Nutritional Balancing and Hair Mineral Analysis. 1991. A Comprehensive Guide, Wilson L.D. Consultans, Inc., 1-330.

[15] Zawadzki M., poręba R., Gać P. 2006. Mechanizmy i skutki toksycznego oddziaływania ołowiu na układ krążenia. [Mechanisms and toxic effects of lead on the cardiovascular system]. Medycyna Pracy, 57, 6, 543-549. 